\title{
Effects of time after ovariectomy, season and oestradiol on luteinizing hormone and follicle-stimulating hormone secretion in ovariectomized ewes
}

\author{
I. B. J. K. Joseph*, W. D. Currie† and N. C. Rawlings \\ Department of Veterinary Physiological Sciences, Western College of Veterinary Medicine, \\ University of Saskatchewan, Saskatoon, Saskatchewan, Canada, S7N OWO
}

\begin{abstract}
Summary. During the breeding season, five groups of three ewes were implanted at ovariectomy with $0.36,0.5,1.0$ and $6.0 \mathrm{~cm}$ oestradiol implants or implants containing no steroid. Eleven days after receiving implants, blood samples were taken every $10 \mathrm{~min}$ for $6 \mathrm{~h}$; implants were then removed. Treatments were repeated three times during each of two consecutive breeding seasons and four times during the intervening anoestrus. In ovariectomized ewes without steroid treatment, luteinizing hormone $(\mathrm{LH})$ pulse frequency increased from early to mid-breeding season, decreased to a minimum at mid-anoestrus and increased to reach a maximum at the mid-point of the second breeding season, subsequently declining. LH pulse amplitude was inversely related to frequency. Basal serum LH concentrations decreased gradually from the first breeding season to reach a minimum at mid-anoestrus and gradually increased to reach a maximum at the end of the second breeding season. Mean serum LH and folliclestimulating hormone ( $\mathrm{FSH}$ ) concentrations were higher at the end of the second breeding season compared with the beginning of the first breeding season.

All parameters of gonadotrophin secretion were decreased much more by oestradiol during the anoestrus than during the breeding season. LH pulse frequency was decreased during anoestrum and at high oestradiol concentrations during the first breeding season. Apart from LH pulse amplitude, the decreases in all parameters of gonadotrophin secretion were less during the second compared with the first breeding season. The minimum effective dose of oestradiol required to decrease mean and basal serum concentrations of $\mathrm{LH}$ during anoestrus was lower than in the breeding season. The minimum effective dose of oestradiol required to decrease mean serum concentrations of FSH was lower in the first compared with the second breeding season. Oestradiol depression of LH pulse amplitude and mean serum concentrations of $\mathrm{LH}$ and FSH showed a dose dependency during the breeding season. During anoestrus dose dependency was seen for basal concentrations of LH and mean serum concentrations of LH and FSH. We conclude that significant chronic changes in gonadotrophin secretion occur in the ewe with time after ovariectomy. Sensitivity to oestradiol also changes, and the effects of oestradiol are not always dose dependent. We suggest that the circannual pattern of LH pulse frequency and basal LH secretion are directly linked to the circannual cycle of photoperiod. Enhanced negative feedback depression of tonic gonadotrophin secretion by oestradiol during anoestrus may be symptomatic or result from the LH pulse generating systems being depressed below a certain threshold by a steroid independent mechanism, directly linked to the circannual cycle of photoperiod.
\end{abstract}

\footnotetext{
*Present address: Department of Population Dynamics, Johns Hopkins University, Baltimore, Maryland, MD 21205, USA.

†Present address: Department of Obstetrics and Gynecology, Grace Hospital, University of British Columbia, Vancouver, British Columbia, Canada.
} 
Keywords: ewe; follicle-stimulating hormone; negative feedback; oestradiol; ovariectomy; pulsatile luteinizing hormone; season

\section{Introduction}

Withdrawal of ovarian steroids by ovariectomy leads to rapid and possibly long-term changes in the tonic secretion of gonadotrophins (Martin, 1984; Webb et al., 1985). However, the reported changes in mean and basal serum concentrations of $\mathrm{LH}$ and $\mathrm{LH}$ pulse frequency and amplitude differ between studies; there is little information about FSH (Karsch et al., 1980; Goodman et al., 1982; Montgomery et al., 1985, 1987; Thomas et al., 1988). Secretory patterns for gonadotrophins in ovariectomized ewes, without steroid treatment, do show some loose linkage to the annual cycle of photoperiod, but this often appears to be lost in ovariectomized ewes that have been ovariectomized for longer (Karsch et al., 1980; Goodman et al., 1982; Montgomery et al., 1985, 1987; Robinson et al., 1985; Thomas et al., 1988). A clear understanding of the changes of tonic gonadotrophin secretion after ovariectomy and with season would seem essential to make full use of the ovariectomized ewe as a model for studies on gonadotrophin secretion and seasonal breeding.

Oestradiol has been shown to depress tonic gonadotrophin secretion during the breeding season, with a marked enhancement of this effect during anoestrus (Pant et al., 1978; Goodman \& Karsch, 1980; Goodman et al., 1980; Karsch et al., 1980; Goodman et al., 1981a; Rawlings et al., 1984). However, when mean and basal serum LH concentrations and LH pulse frequency and amplitude are considered, many disagreements are found (Goodman et al., 1982; Martin et al., 1983; Montgomery et al., 1985, 1987; Thomas et al., 1988). In the few studies on the effects of oestradiol on FSH secretion, depression was suggested (Goodman et al., 1981b; Rawlings et al., 1984; Webb et al., 1985). It is unclear whether the effects of oestradiol on gonadotrophin secretion are dose related, although this has been suggested in anoestrus ewes (Goodman et al., 1980; Thomas et al., 1988). It has been suggested that the annual cycle of photoperiod regulates tonic gonadotrophin secretion primarily by an oestradiol-dependent mechanism, while a steroid-independent mechanism is equivocal (Robinson et al., 1985; Goodman, 1988).

The present study was therefore designed to (I) characterize the tonic gonadotrophin secretory patterns in the ovariectomized ewe with time after ovariectomy, (2) detect the lowest effective dose of serum oestradiol that would depress basal gonadotrophin secretion during the breeding season and anoestrus and to test for a dose-response and (3) examine the pattern and interrelationship of steroid-independent and oestrogen-dependent photoperiodic regulation of tonic gonadotrophin secretion during the breeding season and anoestrus.

\section{Materials and Methods}

\section{Experimental animals}

Fifteen sexually mature Rambouillet $\times$ Columbia crossbred ewes were kept outdoors in dry lots, except during periods of experimentation. During the periods of treatment the ewes were moved indoors and kept under fluorescent lighting, with light exposure set to simulate normal day length. The ewes were fed rations of alfalfa pellets supplemented with hay. Cobalt iodized salt and water were freely available. Oestrus was synchronized using a 12 day treatment of intravaginal sponges containing $60 \mathrm{mg}$ medroxyprogesterone acetate (Veramix: Tuco Products Company, Orangeville, Ontario, Canada). Six days after oestrus, ovariectomy was performed at mid-ventral laparotomy under general anaesthesia. The presence of corpora lutea in all ewes at ovariectomy confirmed that they were cycling at the onset of the experiment.

\section{Implants}

The steroid implants were prepared by mixing $10 \%(\mathrm{w} / \mathrm{w})$ steroid with liquid medical grade elastomer (Silastic, 382 Medical grade elastomer: Dow Corning, Midland, MI, USA) and a curing catalyst (Catalyst: Dow Corning, Midland, 
MI, USA). The oestradiol (Sigma Chemical Company, St Louis, MO, USA) elastomer mixture was injected into Silastic tubing, $0.22 \mathrm{~cm}$ i.d. $\times 0.24 \mathrm{~cm}$ o.d. or $0.32 \mathrm{~cm}$ i.d. $\times 0.48 \mathrm{~cm}$ o.d. (Dow Corning, Midland, MI, USA). The oestradiol implants were cut into appropriate lengths (Table 1).

Table 1. Dimensions of oestradiol implants, mean in vitro concentrations of oestradiol released per day over 19 days ( $n=57$ in all cases) and mean serum oestradiol concentrations created in ovariectomized ewes during all three seasons ( $n=30$ in all cases)

\begin{tabular}{|c|c|c|}
\hline $\begin{array}{l}\text { Dimension of oestradiol } \\
\text { implant }(\text { diameter } \times \text { length }) \\
(\mathrm{cm} \times \mathrm{cm})\end{array}$ & $\begin{array}{l}\text { In vitro concentration of } \\
\text { oestradiol } \\
\text { (ng ml 'saline day ') }\end{array}$ & $\begin{array}{l}\text { Serum oestradiol } \\
\text { concentration } \\
\text { (pg ml ') }\end{array}$ \\
\hline Blank $(0.32 \times 1 \cdot 0)$ & - & $3 \cdot 19 \pm 0 \cdot 14^{\mathrm{a}}$ \\
\hline $0.22 \times 0.36$ & $61 \pm 6^{a}$ & $5 \cdot 07 \pm 0.15^{\mathrm{b}}$ \\
\hline $0.32 \times 0.50$ & $180 \pm 13^{b}$ & $7 \cdot 09 \pm 0.14^{\mathrm{c}}$ \\
\hline $0 \cdot 32 \pm 1 \cdot 0$ & $259 \pm 14^{\mathrm{c}}$ & $8 \cdot 96 \pm 0 \cdot 20^{d}$ \\
\hline $0.32 \pm 6.0$ & $818 \pm 46^{\mathrm{d}}$ & $15.8 \pm 0.99^{\mathrm{e}}$ \\
\hline
\end{tabular}

Numbers in columns with different superscripts are significantly different $(P<0.05)$.

The implants were incubated in sterile $0.9 \%(\mathrm{w} / \mathrm{v}) \mathrm{NaCl}$ (saline) for $24 \mathrm{~h}$, at $37^{\circ} \mathrm{C}$, under constant agitation, before insertion. Implants were introduced subcutaneously in the axillary region under local anaesthesia (Duracaine: Roger/ STB Inc., Montreal, Quebec, Canada).

The release pattern of steroid from the oestradiol implants were checked in vitro. The implants were placed in $16 \mathrm{~cm} \times 150 \mathrm{~cm}$ borosilicate glass tubes $(n=3)$ and $18 \mathrm{ml}$ of $0.1 \%$ phosphate-buffered saline (PBS) was added to each tube and incubated at $37^{\circ} \mathrm{C}$ in a water bath under constant agitation. At the end of $24 \mathrm{~h}$, a $5 \mathrm{ml}$ sample of buffer was withdrawn from each tube and the remainder was discarded and replaced with $18 \mathrm{ml}$ of fresh $0.1 \%$ PBS. The procedure was repeated for 19 days and the samples were frozen until assayed for oestradiol.

\section{Experimental protocol}

Five groups of three ewes were implanted at ovariectomy in late October (early breeding season) with four different sizes of Silastic rubber implants containing oestradiol, or with blank implants containing no steroid (Table 1). Implants were left in place for 12 days and blood samples $(10 \mathrm{ml})$ were collected by jugular venepuncture every other day for measurement of serum oestradiol concentrations. Ten days after implantation (early November), indwelling jugular catheters (i.d. 1.00 mm; o.d. $1.50 \mathrm{~mm}$, SV-70, Dural Plastics and Engineering, Dural, NSW) were inserted and on day 11 blood samples were collected every $10 \mathrm{~min}$ for $6 \mathrm{~h}$, for characterization of tonic LH and FSH secretion. All scrum samples were stored at $-20^{\circ} \mathrm{C}$ until assayed for oestradiol, FSH and LH.

At six week intervals, the same group of ewes was randomly redistributed to the implant treatment groups described in Table 1. Ewes were treated three times during each of two consecutive breeding seasons and four times during the intervening single anoestrus, with the last treatment in mid-January, that is, late in the second breeding season, to give a total of ten periods of treatment. Demarcation of breeding season was based on previous observations (Jeffcoate et al., 1984).

\section{Hormone assays}

Serum concentrations of FSH and LH were determined in validated radioimmunoassays (Rawlings et al., 1984; Currie \& Rawlings, 1989). Concentrations of FSH and LH are expressed in terms of NIDDK-oFSH-RP1 and NIDDK-oLH-24, respectively. The sensitivity of the gonadotrophin and oestradiol assays is expressed as the lowest standard different from zero, using an unpaired $t$ test. The limit of detection was $0.25 \mathrm{ng} \mathrm{ml}^{-1}$ and $0.06 \mathrm{ng} \mathrm{ml}^{-1}$ for FSH and LH, respectively. Intra- and inter-assay coefficients of variation (CVs) for ovine reference sera with mean FSH concentrations of 14.1 or $1.13 \mathrm{ng} \mathrm{ml}^{-1}$ were $6.6 \%(n=8)$ and $9.6 \%(n=87)$ or $7.6 \%(n=11)$ and $9.7 \%(n=$ $110)$ respectively. Intra- and inter-assay CVs for ovine reference sera with mean LH concentration of 3.01 or $0.15 \mathrm{ng} \mathrm{ml}$ ' were $5.0 \%(n=18)$ and $9.9 \%(n=110)$ or $9.6 \%(n=18)$ and $14.9 \%(n=110)$, respectively.

Oestradiol was measured using a modification of an assay previously validated and published (Rawlings et al., 1984; Currie \& Rawlings, 1989). The changes were that ether extracts of serum were assayed without the previous partition step and the assay standards were prepared in charcoal stripped serum and extracted with ether before assay, rather than being put directly into assay tubes. Extraction efficiency was $87 \pm 0.5 \%(n=96 ; x \pm \mathrm{SD})$. Sensitivity was $1 \mathrm{pg} \mathrm{ml}$ ' serum. When extracts of charcoal stripped serum were analysed, values did not differ significantly from zero $(P>0 \cdot 10)$. When 2 or $10 \mathrm{pg}$ of oestradiol was added to $1 \mathrm{ml}$ of serum from ewe, the values obtained after correction for endogenous oestradiol were $2.6 \pm 0.25 \mathrm{pg}(n=96)(\bar{x} \pm \mathrm{SD})$ and $11 \cdot 2 \pm 0.34 \mathrm{pg}(n=97)$ respectively. Serum 
concentrations of oestradiol measured in this assay in ovariectomized ewes, were $3 \cdot 2 \pm 0 \cdot 1 \mathrm{pg} \mathrm{ml} \quad(\bar{x} \pm \mathrm{SD})$ and, in intact ewes, were $4.7 \pm 0.7 \mathrm{pg} \mathrm{ml}^{-1}$ and $12.7 \pm 3.3 \mathrm{pg} \mathrm{ml}^{\prime}$ in the midluteal and follicular phases of their oestrous cycles, respectively. These values are similar to those previously published (Pant et al., 1977; Rawlings et al., 1977; Herriman et al., 1979; Hauger et al., 1977). For sera with oestradiol concentrations of $23 \mathrm{pg} \mathrm{ml} \mathrm{',} 11 \cdot 3 \mathrm{pg} \mathrm{ml}$ ' or $8.8 \mathrm{pg} \mathrm{ml}$ ', intra- and inter-assay CVs were $7 \cdot 3 \%(n=2)$ and $9 \cdot 1 \%(n=10), 11 \%(n=2)$ and $11.6 \%(n=10)$ or $9 \cdot 4 \%(n=2)$ and $12 \cdot 5 \%(n=11)$, respectively.

\section{Statistical analysis}

The PULSAR program (Merriam \& Wachter, 1982) was used to identify LH pulse frequency in pulses h ', amplitude in $\mathrm{ng} \mathrm{ml}$ ', basal serum $\mathrm{LH}$ and mean serum $\mathrm{LH}$ concentrations ( $\mathrm{ng} \mathrm{ml}$ ' serum). Basal serum $\mathrm{LH}$ values are those after termination of pulses. According to this method serum FSH concentrations did not show evidence of pulsatility and are expressed in $\mathrm{ng} \mathrm{ml}$ 'serum.

Concentrations of oestradiol produced by the implants in vitro, over a 19 day period, were analysed using a twoway analysis of variance (ANOVA) and least squares difference (LSD) test (Steel \& Torrie, 1980). The data for the first day of in vitro incubation were excluded from analysis because they were equivalent to the preincubation of the implants used in vivo. A correlation analysis was run between concentrations of oestradiol produced by implants in vitro and in vivo and these values and implant size.

Serum oestradiol concentrations for samples taken every other day during implant treatment of ewes and the serum LH and FSH data collected from the frequent bleeding at the end of each implant treatment period, were initially analysed using $5 \times 10$ factorial anOvas. Implant type or size (blank and various sizes of oestradiol implants) and period of treatment were the main effects. To isolate an interaction between oestradiol implant size and period of treatment, were analysed LH and FSH data for the first and second breeding seasons and the anoestrus, in separate $5 \times 6$ and $5 \times 4$ factorial ANOVAs, respectively. As serum oestradiol concentrations did not differ between periods of treatment, data for all periods of treatment were combined to correlate with the in vitro data for oestradiol release from the various sizes of implants.

The LH and FSH data from control ewes were re-analysed in a one-way ANOva to show steroid independent effects of season and/or time after ovariectomy.

The percentage depression by oestradiol (difference between treatment and control, expressed as a percentage of control for the respective period of treatment) of each parameter of serum LH and FSH data was calculated to demonstrate steroid-dependent depression of tonic LH and FSH secretion. The percentage depression data, from animals treated with $0.5,1$ and $6 \mathrm{~cm}$ implants, were analysed as a $3 \times 10$ factorial ANOvA. The data from the animals treated with the $0.36 \mathrm{~cm}$ implant size were excluded from this analysis as the initial statistical analysis showed that this implant had little influence on tonic gonadotrophin secretion. A chi-square goodness-of-fit test was performed to determine the significance of the number of ovariectomized ewes that demonstrated LH pulses across all three seasons, when treated with $0.5,1.0$ and $6.0 \mathrm{~cm}$ sizes of oestradiol implants.

\section{Results}

\section{In vitro and in vivo oestradiol release pattern}

The concentrations of oestradiol produced in vitro and in vivo (Table I) were positively correlated with the implant size, $r=0.99(P<0.05)$ and $r=0.95(P<0.05)$, respectively, and with each other, $r=0.99(P<0.05)$. Concentrations of oestradiol created in vitro or in vivo by oestradiol implants were slightly increased for the first 3 days and then remained stable for the next 17 or 9 days, respectively. The concentrations of oestradiol created by each size of oestradiol implant differed from all other implant sizes in vitro and in vivo. In vivo and in vitro, the oestradiol concentrations created by the smallest oestradiol implant $(0.36 \mathrm{~cm})$ differed from that recorded for the control implant.

\section{Effects of time after ovariectomy and season on gonadotrophin secretion in ovariectomized ewes with no oestradiol treatment}

LH pulse amplitude was highest at mid-anoestrus (Fig. 1), with gradual transitions to and from the low points seen at the middle of each breeding season $(P<0.05)$. Pulse frequency of LH showed the opposite trend and was negatively correlated with amplitude $(r=-0.91, P<0.05)$.

Mean serum LH concentrations were stable during the first breeding season and early anoestrus, rising subsequently to a peak late in the second breeding season $(P<0.05)$. Basal serum LH concentrations fell from the middle of the first breeding season to mid-anoestrus and then rose to their highest concentration late in the second breeding season $(P<0.05)$. Mean serum FSH concentration increased $(P<0.05)$ from the first $\left(11.6 \pm 1.12 \mathrm{ng} \mathrm{m}^{-1}\right)$ to the second $\left(24 \cdot 3 \pm 2.59 \mathrm{ng} \mathrm{ml}^{-1}\right)$ breeding season, no seasonal pattern was noted (Fig. 1). 
(a)
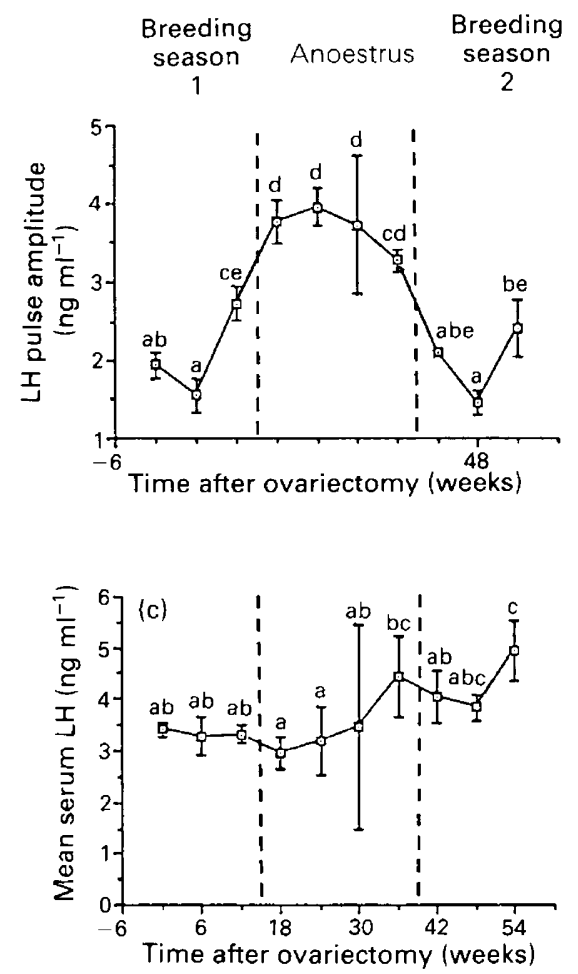

(b)
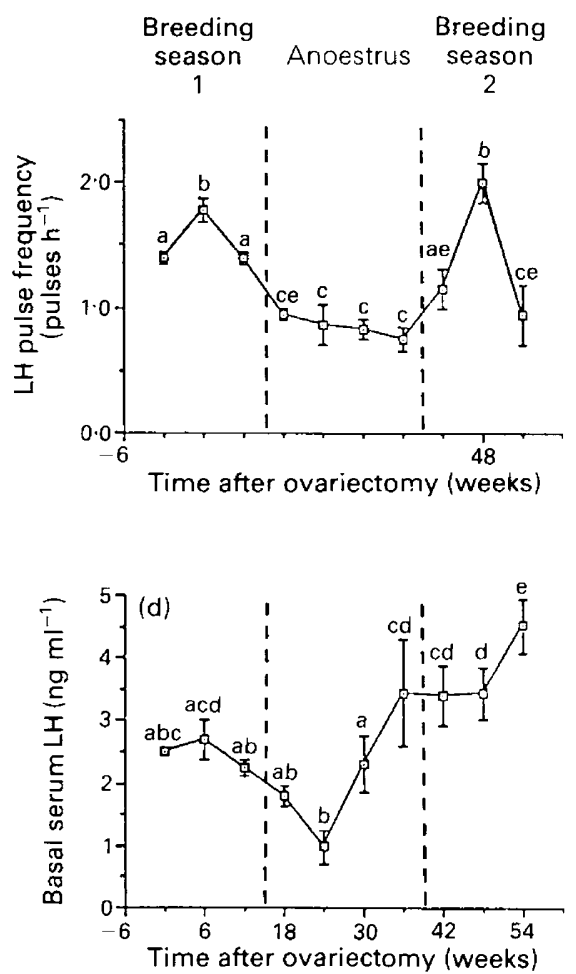

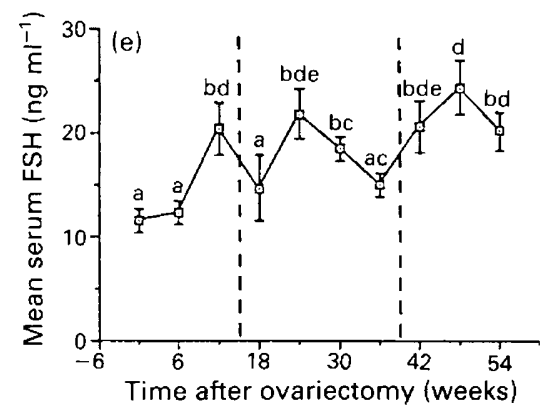

Fig. 1. Changes in LH pulse amplitude (a), pulse frequency (b), mean serum LH (c), basal serum LH (d) and mean serum FSH (e) concentrations in ovariectomized ewes without oestradiol treatment. Blood was sampled every $10 \mathrm{~min}$ for $6 \mathrm{~h}$ on 10 occasions $(n=3$ in all cases). The first blood sampling was in the early breeding season (mid-October), 11 days after ovariectomy, with subsequent samplings at 6-week intervals through anoestrus and to the latter part of a second breeding season (mid-January). Different letter superscripts indicate significant differences $(P<0 \cdot 05)$.

\section{Depression of gonadotrophin secretion by oestradiol and the effects of size of oestradiol implant, time after ovariectomy and season}

The effects of oestradiol implant size and period of treatment were shown to be significant in an initial $5 \times 10$ factorial analysis $(P<0.05)$. The interaction between implant size and period of treatment was significant $(P<0.05)$ for mean and basal serum concentrations of LH; these interactions disappeared when the data for anoestrus were removed from the analysis. 
(a) Effects of size of oestradiol implant. Serum gonadotrophin data for ewes with implants are summarized by implant type and size and by season (Figs 2-4). This simplification of the data presentation was justified because there were few individual treatment period effects within season but there were seasonal effects and an interaction between season and implant size. Serum oestradiol concentrations created by the $0.36 \mathrm{~cm}$ oestradiol implant depressed mean serum FSH concentrations during the first breeding season and mean and basal serum concentrations of LH during anoestrus only. The serum oestradiol concentrations created by the $0.5,1.0$ and $6.0 \mathrm{~cm}$ oestradiol implants depressed LH pulse amplitude and mean serum concentrations of $\mathrm{LH}$ and FSH during all three seasons of study (Figs 2-4). Dose dependency was apparent for mean serum concentrations of LH and FSH and LH pulse amplitude during all three seasons with the exception of LH pulse amplitude during anoestrus. Dose dependency during the breeding season is illustrated for representative ewes in Fig. 5. The serum oestradiol concentrations created by the $0.5,1 \cdot 0$ and $6.0 \mathrm{~cm}$ implants depressed $\mathrm{LH}$ pulse frequency during anoestrus, but during the breeding season, only the oestradiol concentrations created by the $6 \mathrm{~cm}$ implant decreased LH pulse frequency and then only during the first breeding season. Basal serum concentrations of LH were depressed at all seasons, but in the later breeding season only the $6 \mathrm{~cm}$ implant was effective (Figs 2-4); dose dependency was indicated only during anoestrus.

(b) Effects of season and time after ovariectomy. The variation in the percentage depression of gonadotrophin secretion by oestradiol with season and time after ovariectomy and the data for ewes treated with the $0.5,1.0$ and $6.0 \mathrm{~cm}$ implants were combined for summarization (Fig. 6). Data for ewes treated with the $0.36 \mathrm{~cm}$ implant were excluded as this implant produced only limited effects on parameters of gonadotrophin secretion. This data presentation is an attempt to simplify and illustrate the seasonal pattern of oestradiol effects on gonadotrophin secretion separately from trends in gonadotrophin secretion that are independent of oestradiol negative feedback. Depression of all parameters of gonadotrophin secretion by the serum oestradiol concentrations created by the $0.5,1.0$ and $6.0 \mathrm{~cm}$ oestradiol implants was greatest during anoestrus compared with either breeding season $(P<0.05)$. Depression of all parameters of gonadotrophin secretion, except for tonic LH pulse amplitude, was greater in the first compared with the second breeding season $(P<0.05)$. The transition in the depression of parameters of gonadotrophin secretion from breeding season to anoestrus was abrupt, except for LH pulse amplitude and mean serum concentrations of FSH, where the degree of depression changed gradually from mid-breeding season to midanoestrus. A similar gradual transition was also seen for $\mathrm{LH}$ pulse frequency from anoestrus to the second breeding season (Fig. 6). During anoestrus, from the earliest to latest treatment period, 3/9, $0 / 9,1 / 9$ and $6 / 9$ ewes had pulses respectively. During the breeding seasons, no fewer than $8 / 9$ ewes had pulses at the six treatment periods. The calculated $\chi^{2}$ statistic $\left(\chi^{2}=18 \cdot 8\right)$ was significant $(P<0 \cdot 05)$, indicating a significant difference between breeding season and anoestrus.

\section{Discussion}

These results show that ovariectomized ewes not treated with oestradiol have a circannual pattern of LH pulse frequency apparently linked to the annual pattern of photoperiod. Pulse frequency of LH was at its peak at mid-breeding season in December and lowest in mid-anoestrus in June-July. In intact ewes ovulation rate is at its peak in mid-breeding season (Ortavant et al., 1988). These photoperiod-linked patterns in LH pulse frequency have not always been noticed in the past. In Ile-de-France ewes, ovariectomized during the breeding season and followed for one year, $\mathrm{LH}$ pulse frequency and amplitude both appeared to peak in the middle of the first breeding season of the study, but no such pattern was seen in the subsequent breeding season (Montgomery et al., 1985). In ovariectomized Suffolk ewes studied for one year, LH pulse frequency was low in the initial anoestrous period of the study (Robinson et al., 1985), rose during the early breeding season but then remained fairly constant, with a limited decline during the ensuing seasonal anoestrus. In 

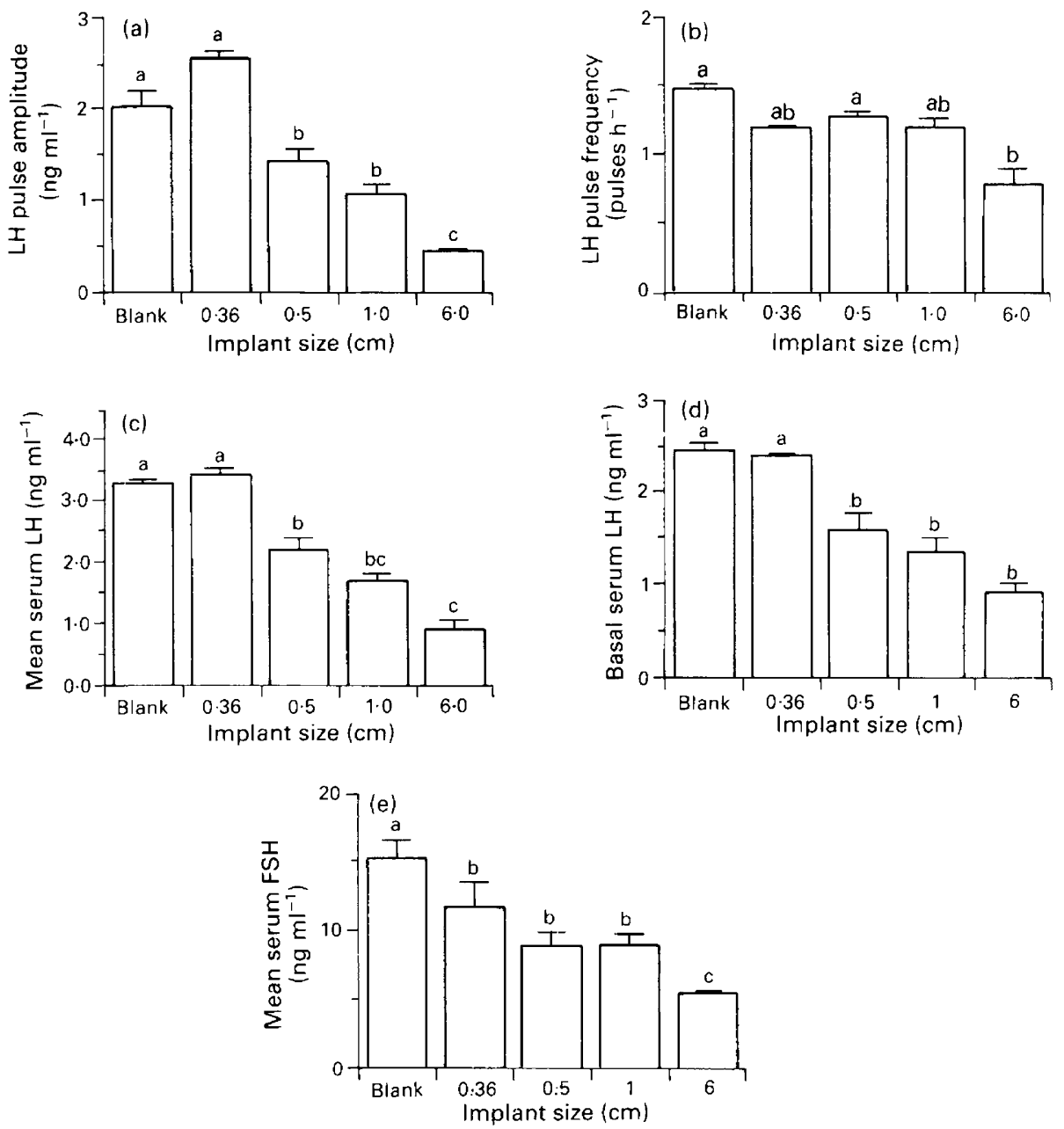

Fig. 2. LH pulse amplitude (a), LH pulse frequency (b), mean serum LH (c), basal serum LH (d) and mean serum FSH (e) concentrations in ovariectomized ewes treated with different sizes of oestradiol implants during the first breeding season of the study ( $n=12$ in all cases). Data are based on blood samples taken every $10 \mathrm{~min}$ for $6 \mathrm{~h}, 1 \mathrm{l}$ days after insertion of implants; implants were inserted at ovariectomy and again 6 and 12 weeks later. Different letter superscripts indicate significant differences $(P<0 \cdot 05)$.

the present study, LH pulse amplitude was inversely related to frequency; this relationship has been seen before in some (Karsch et al., 1980) but not all studies (Rawlings et al., 1984; Montgomery et al., 1985). This suggests that as LH pulse frequency increases, there is less LH available for each pulse (Clarke \& Cummins, 1985).

The marked annual cycle of basal serum LH concentrations in our untreated ovariectomized ewes was not found by Montgomery et al. (1985), but in both cases an increase in basal LH secretion occurred with time after ovariectomy. This emphasizes the possible existence of basal secretion of $\mathrm{LH}$ as an entity unrelated to $\mathrm{LH}$ pulse frequency. The increase in basal serum $\mathrm{LH}$ concentrations, with time after ovariectomy, caused the increase in mean serum LH concentrations seen in the second breeding season of the present study. These long-term shifts in basal and mean serum LH concentrations after ovariectomy have not always been evident in the past (Goodman \& Karsch, 1981). 

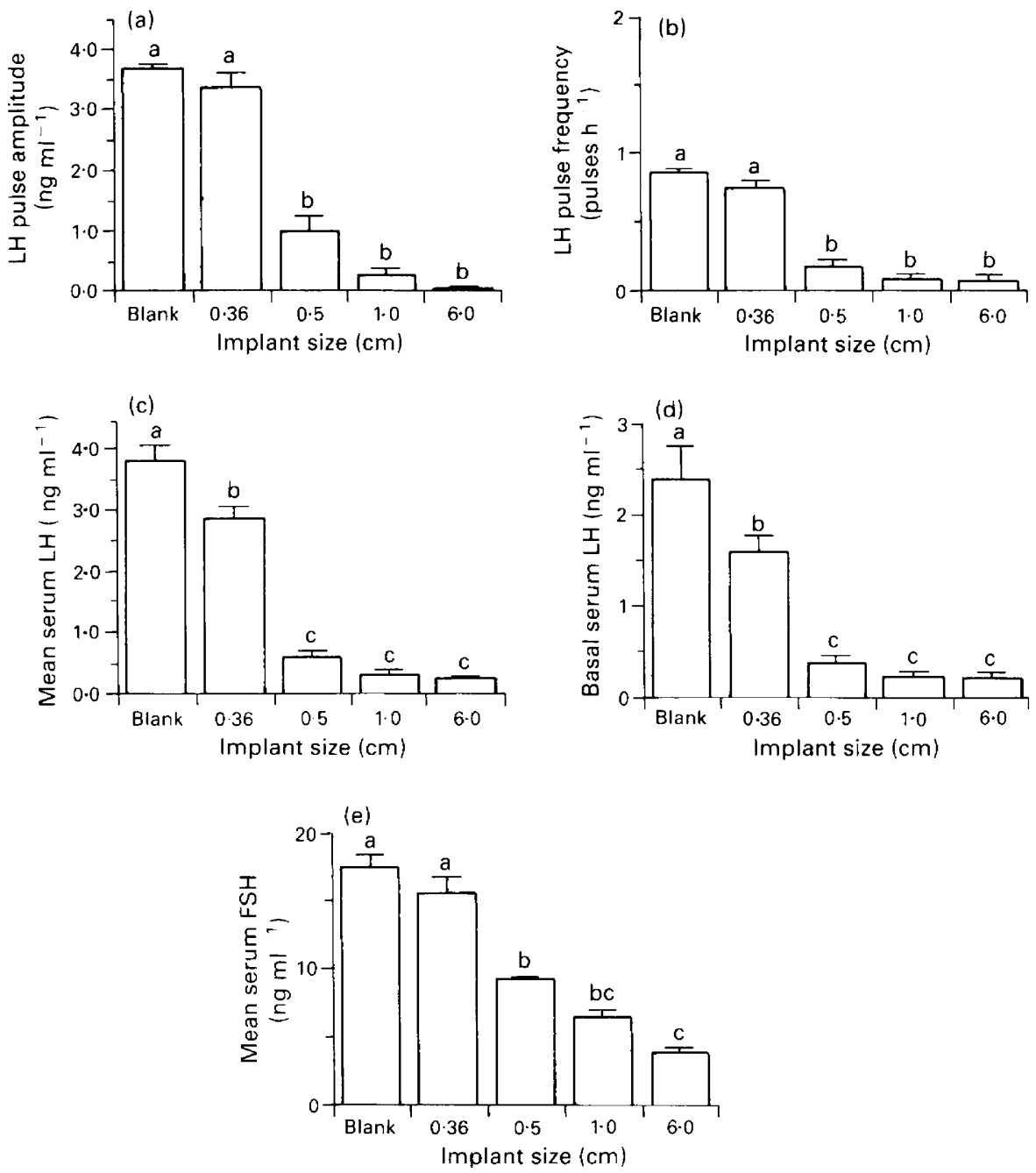

Fig. 3. LH pulse amplitude (a), LH pulse frequency (b), mean serum LH (c), basal serum LH (d) and mean serum FSH (e) concentrations in ovariectomized ewes treated with different sizes of oestradiol implants during anoestrus ( $n=12$ in all cases). Data is based on blood samples taken every $10 \mathrm{~min}$ for $6 \mathrm{~h}, 11$ days after insertion of implants. Implants were inserted at 18, 24, 30 and 36 weeks after ovariectomy. Different letter superscripts indicate significant differences $(P<0 \cdot 05)$.

The lack of variation in mean serum concentrations of LH with season in our untreated ovariectomized ewes agrees with previous findings (Goodman \& Karsch, 1981). The fairly constant mean serum LH concentration seen over most of the present study reflect the inverse relationship between LH pulse frequency and both basal LH concentrations and LH pulse amplitude.

In studies on the control of gonadotrophin secretion in ewes less consideration has been given to FSH. Our results and those of Montgomery et al. (1987) show that mean serum concentrations of FSH rise with time after ovariectomy, with little apparent influence of season.

The serum concentrations of oestradiol produced by the implants in the present study encompassed a similar range to those for intact ewes. The reports of effects of oestrogen treatment on LH pulse amplitude in ovariectomized ewes are inconsistent. There are reports ranging from a small increase (Goodman et al., 1982; Martin et al., 1983; Thomas et al., 1988), or no effect (Thomas et 

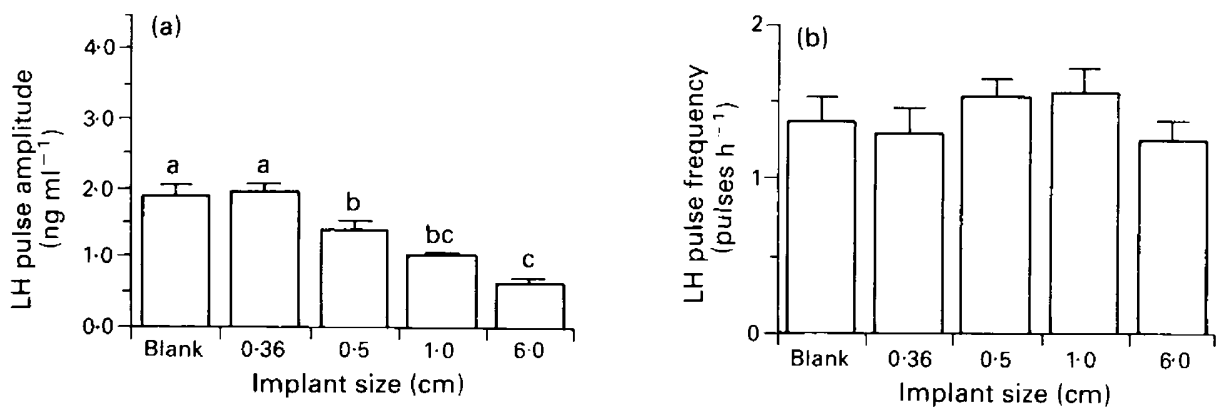

(d)
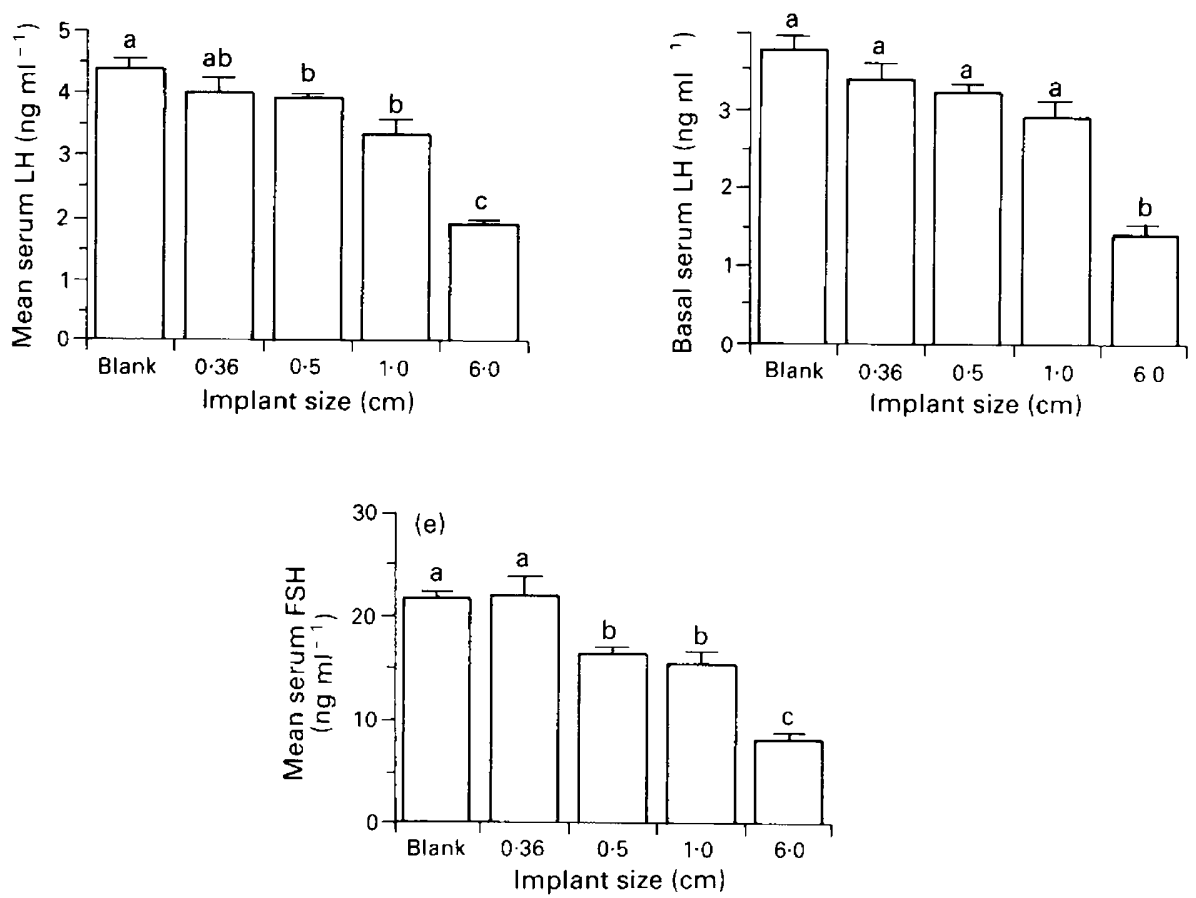

Fig. 4. LH pulse amplitude (a), LH pulse frequency (b), mean serum LH (c), basal serum LH (d) and mean serum FSH (e) concentrations in ovariectomized ewes treated with different sizes of oestradiol implants during the second breeding season of the study ( $n=12$ in all cases). Data are based on blood samples taken every $10 \mathrm{~min}$ for $6 \mathrm{~h}, 11$ days after insertion of implants. Implants were inserted at 42,48 and 54 weeks after ovariectomy. Different letter superscripts indicate significant differences $(P<0.05)$.

al., 1988), to a marked reduction (Pant et al., 1978; Goodman \& Karsch, 1980; Goodman et al., 1981 b; Rawlings et al., 1984), both during the breeding season and seasonal anoestrus. These conflicting results are probably due to variation in the doses of oestrogens used and, perhaps, the breed of ewe. The influence of oestradiol on LH pulse amplitude in our work indicated a hypersensitivity of the hypothalamic-pituitary axis to the negative feedback effect of oestradiol during anoestrus, but a similar threshold for effect.

Previous studies have not revealed a reduction in the frequency of LH pulses by oestradiol during the breeding season (Goodman \& Karsch, 1980; Goodman et al., 1981b; Thomas et al., 1988). This was largely confirmed in our study. The ability of oestradiol to depress LH pulse 


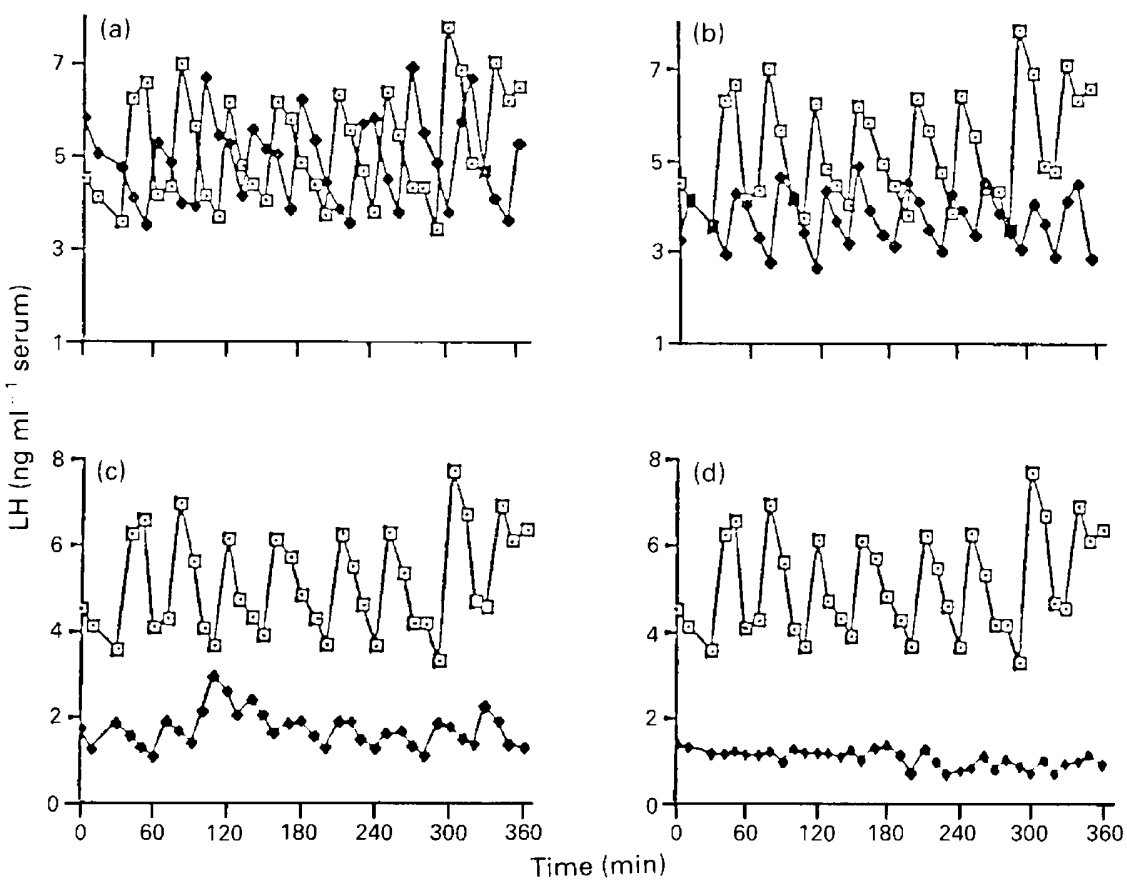

Fig. 5. Serum LH profile of an ovariectomized ewe (control) (๑) with no oestradiol treatment and representative ovariectomized ewes $(\bullet)$ treated with $0.36 \mathrm{~cm}(\mathrm{a}), 0.5 \mathrm{~cm} \mathrm{(b)}, 1.0 \mathrm{~cm}$ (c) and $6.0 \mathrm{~cm}(\mathrm{~d})$ of oestradiol implants during the first breeding season of the study (treatment period 2). Implants were in place for 11 days before blood was sampled every $10 \mathrm{~min}$ for $6 \mathrm{~h}$. Ovariectomy was performed approximately 7 weeks prior to this blood sampling period.

amplitude, but not frequency, in the ovariectomized ewe, during the breeding season, is in agreement with previous reports (Goodman \& Karsch, 1980; Goodman et al., 1981b, 1982). Reduction of LH pulse frequency by oestradiol during anoestrus has been well documented (Goodman \& Karsch, 1980; Goodman et al., 1981b, 1982). However, our observations did not reveal dose dependency, in contrast with other reports (Thomas et al., 1988), where a marked dose dependency was noted during anoestrus.

Reports on the effect of oestradiol on mean and basal serum LH concentrations and mean serum FSH concentrations in ovariectomized ewes are sparse. Oestradiol has been shown to depress mean serum concentrations of LH during the breeding season and anoestrus in ovariectomized ewes, with greater depression seen during anoestrus (Goodman et al., 1980; Karsch et al., 1980; Goodman et al., 1981a). However, in previous studies a dose response was not evident (Goodman et al., 1980). Our data show that depression of mean serum LH concentrations by oestradiol during the breeding season reflects depression of LH pulse amplitude and basal serum LH concentrations. The greater depression of mean serum LH concentrations by oestradiol during anoestrus would appear to reflect the additional reduction of LH pulse frequency, as well as greater depression of LH pulse amplitude and basal serum concentrations of LH. Oestradiol administration during the breeding season has been found to have no effect on basal LH in ovariectomized Suffolk ewes and actually caused an increase in Merinos (Thomas et al., 1988).

Oestradiol can suppress FSH concentrations in ovariectomized ewes during the breeding season (Goodman et al., 1981a) and anoestrus (Webb et al., 1985). In addition to this, data from the present study demonstrated a clear dose-response relationship during the breeding season and anoestrus with a threshold for effect, and a greater depression during anoestrus. In general, the ability of oestradiol to depress gonadotrophin secretion decreased with time in our ovariectomized 
(a)
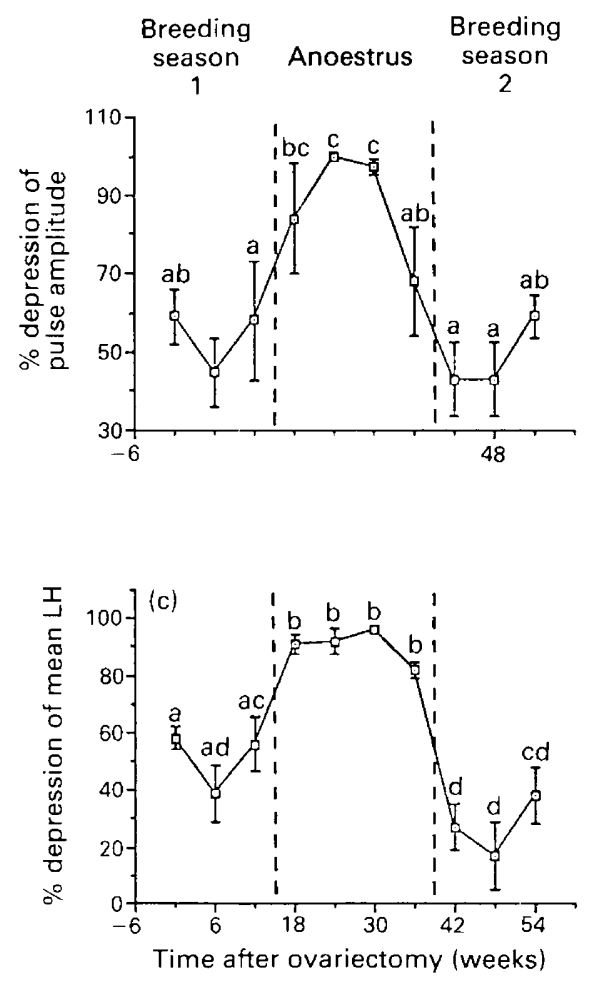

(b)
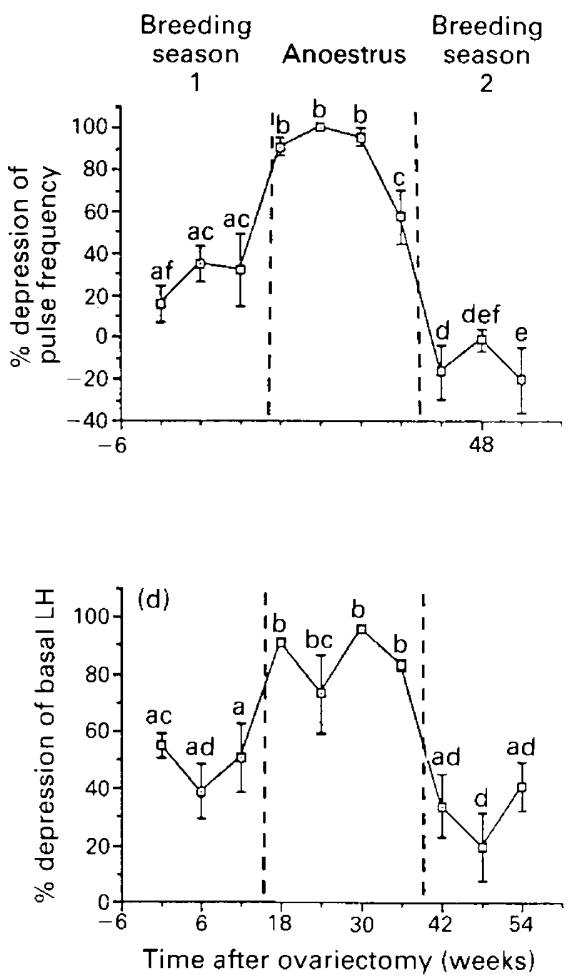

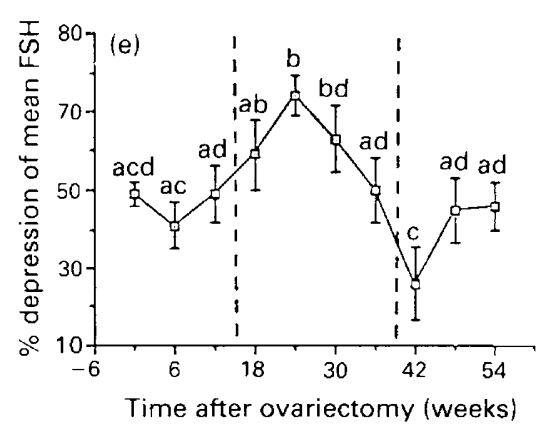

Fig. 6. Depression of LH pulse amplitude (a), pulse frequency (b), mean serum LH (c), basal serum LH (d) and mean serum FSH (e) concentrations in ovariectomized ewes, by serum oestradiol concentrations created by $0.5,1.0$ and $6.0 \mathrm{~cm}$ implants. Depression is expressed as a percentage of control values (see text for details). Data points are based on ten separate intensive bleedings, where samples were taken every $10 \mathrm{~min}$ for $6 \mathrm{~h}, 11$ days after implant insertion. Implants were first inserted at ovariectomy early in the breeding season (October) and treatments were repeated every 6 weeks, three times in breeding season 1, four times in anoestrus and three more times in a second breeding season, with the final treatment late in the season (January). Different letter superscripts indicate significant differences $(P<0.05)$. No pulses were recorded at 24 weeks and only one at 30 weeks.

ewes, indicating, as for progesterone, that steroid feedback sensitivity declines with time after ovariectomy (Goodman, 1988).

Measurable serum concentrations of oestradiol were shown to be present in nonoestradioltreated ovariectomized ewes. Charcoal-stripped serum blanks in the assay never gave recorded 
values in terms of the oestradiol standards used. This suggests that some measurable oestradiol is present in ovariectomized ewes, an adrenal source is possible (Montgomery et al., 1985). Oestradiol concentrations in ovariectomized ewes not treated with oestradiol were lower than in those fitted with the smallest oestradiol implant $(0.36 \mathrm{~cm})$. This small implant was, in most instances, ineffective in depressing gonadotrophin secretion allowing the delineation of a threshold concentration of oestradiol for depression of gonadotrophin secretion. The very low concentrations of oestradiol seen in control ewes and ewes treated with the smallest oestradiol implant did not produce significant depression of gonadotrophin secretion. We have assumed that the control ewes in the present study show steroid-independent effects of photoperiod changes. The difference in gonadotrophin values between steroid treated and nonoestradiol-treated ewes should reveal oestradiol-dependent influences.

It has been suggested that steroid-dependent and -independent photoperiod driven control of tonic gonadotrophin secretion in the ovariectomized ewe are different, mainly because their seasonal patterns are quite distinct (Robinson et al., 1985). Steroid-dependent effects changed markedly at the onset and end of anoestrus, but steroid-independent effects followed a less distinct profile (Robinson et al., 1985). In our data a clear annual cycle in basal serum LH concentration and LH pulse frequency and amplitude was seen, which appeared clearly linked to the annual cycle of photoperiod. It could be argued that enhanced negative feedback depression of gonadotrophin secretion by oestradiol is manifest when tonic LH pulse frequency, basal LH secretion or both, fall below a set point and that the depression is removed when the setpoint is reached at the end of anoestrus. This suggests that photoperiod directly influences tonic LH pulse frequency as originally postulated (Goodman \& Karsch, 1981) and that negative feedback sensitivity to oestradiol is not a separate mechanism independently linked to photoperiodic patterns. The superimposition of enhanced negative-feedback depression of gonadotrophin secretion by oestradiol during anoestrus may act as a failsafe mechanism to delimit anoestrus more precisely. Clearly, the enhanced effectiveness of oestradiol in negative-feedback depression of gonadotrophin secretion during anoestrus is dramatic, reversing the steroid-independent trend in tonic LH pulse amplitude and imposing a marked seasonal trend on mean serum concentrations of LH and FSH.

The authors thank Susan Cook for her technical assistance in hormone measurements, lan Irvine and Jane Churchill for assistance in carrying out the experiment. Bovine LH for iodination was provided by Leo Reichert, Jr. Standards for gonadotrophin assays were obtained from NIDDK. Ingrid B. J. K. Joseph was a recipient of a Canadian Commonwealth Scholarship. This work was supported by NSERC, Canada.

\section{References}

Clarke, I.J. \& Cummins, J.T. (1985) GnRH pulse frequency determines $\mathrm{LH}$ pulse amplitude by altering the amount of releasable $\mathbf{L H}$ in the pituitary glands of ewes. J. Reprod. Fert. 73, 425-431.

Currie, W.D. \& Rawlings, N.C. (1989) Fluctuations in responsiveness of $\mathrm{LH}$ and lack of responsiveness of FSH to prolonged infusion of morphine and naloxone in the ewe. J. Reprod. Fert. 86, 359-366.

Goodman, R.L. (1988) Neuroendocrine control of the ovine oestrous cycle. In The Physiology of Reproduction, pp. 1929-1969. Eds E. Knobil \& J.D. Neill. Raven Press, NY.

Goodman, R.L. \& Karsch, F.J. (1980) Pulsatile secretion of luteinizing hormone; differential suppression by ovarian steroids. Endocrinology 107, 1286 1290.

Goodman, R.L. \& Karsch, F.J. (1981) A critique of the evidence on the importance of steroid feedback to seasonal changes in gonadotrophin secretion. $J$. Reprod. Fert. 30, 1-13.

Goodman, R.L., Legan, S.J., Ryan, K.D., Foster, D.L. \& Karsch, F.J. (1980) Two effects of oestradiol that normally contribute to the control of tonic $\mathrm{LH}$ secretion in the ewe. Biol. Reprod. 23, 415-422.

Goodman, R.L., Pickover, S.M. \& Karsch, F.J. (1981a) Ovarian feedback control of follicle stimulating hormone in the ewe: evidence for selective suppression. Endocrinology 108, 772-777.

Goodman, R.L., Bittman, E.L., Foster, D.L. \& Karsch, F.J. (198Ib) The endocrine basis of synergistic suppression of luteinizing hormone by oestradiol and progesterone. Endocrinology 109, 1414-1417.

Goodman, R.L., Bittman, E.L., Foster, D.L. \& Karsch, F.J. (1982) Alterations in the control of LH pulse frequency underlie the seasonal variation in oestradiol 
negative feedback in the ewe. Biol. Reprod. 27, $580-589$.

Hauger, R.L., Karsch, F.J. \& Foster, D.L. (1977) A new concept for control of the estrous cycle of the ewe. Based on the temporal relationships between luteinizing hormone, estradiol and progesterone in peripheral serum and evidence that progesterone inhibits tonic LH secretion. Endocrinology 101, 807-817.

Herriman, I.D., Harwood, D.J., Mallinson, C.B. \& Heitzman, R.J. (1979) Plasma concentrations of ovarian hormones during the oestrous cycle of the sheep and cow. J. Endocr. 81, 61-64.

Jeffcoate, I.A., Rawlings, N.C. \& Howell, W.E. (1984) Duration of the breeding season and response to reproductive manipulation in five breeds of sheep under northern prairie conditions. Theriogenology 22, 279-290.

Karsch, F.J., Goodman, R.L. \& Legan, S.J. (1980) Feedback basis of seasonal breeding: test of an hypothesis. J. Reprod. Fert. 58, 521-535.

Martin, G.B. (1984) Factors affecting the secretion of luteinizing hormone in the ewe. Biol. Rev. 9, 1-87.

Martin, G.B., Scaramuzzi, R.J. \& Henstridge, J.D. (1983) Effects of oestradiol, progesterone and androstenedione on the pulsatile secretion of luteinizing hormone in ovariectomized ewes during spring and autumn. $J$. Endocr. 96, 181-193.

Merriam, G.R. \& Wachter, K.W. (1982) Algorithms for the study of episodic hormone secretion. Am. J. Physiol. 243, E310-E318.

Montgomery, G.W., Martin, G.B. \& Pelletier, J. (1985) Changes in pulsatile LH secretion after ovariectomy in Ile-de-France ewes in two seasons. J. Reprod. Fert. $73,173-183$.

Montgomery, G.W., Martin, G.B., Blanc, M.R. \& Pelletier, J. (1987) Season influences FSH concentration in ovariectomized Ile-de-France ewes. $J$. Reprod. Fert. 80, 271--277.

Ortavant, R., Bocquier, F., Pelletier, J., Ravault, J.P., Thimonier, J. \& Volland-Nail, P. (1988) Seasonality of reproduction in sheep and its control by photoperiod. Aust. J. Biol. Sci. 41, 69-85.

Pant, H.C., Hopkinson, C.R.N. \& Fitzpatrick, R.J. (1977) Concentrations of oestradiol, progesterone, luteinizing hormone and follicle-stimulating hormone in the jugular venous plasma of ewes during the oestrous cycle. J. Endocr. 73, 247-255.

Pant, H.C., Dobson, H. \& Ward, W.R. (1978) Effect of active immunization against oestrogens on plasma gonadotrophins in the ewe and the response to synthetic oestrogen on LH. J. Reprod. Fert. 53, 241-248.

Rawlings, N.C., Kennedy, S.W., Chang, C.H., Hill, J.R. \& Henricks, D.M. (1977) Onset of seasonal anestrus in the ewe. J. Anim. Sci. 44, 791-797.

Rawlings, N.C., Jeffcoate, I.A. \& Rieger, D.L. (1984) The influence of oestradiol-17 $\beta$ and progesterone on peripheral serum concentration of luteinizing hormone and follicle stimulating hormone in the ovariectomized ewe. Theriogenology 22, 473-488.

Robinson, J.E., Radford, H.M. \& Karsch, F.J. (1985) Seasonal changes in pulsatile luteinizing hormone (LH) secretion in the ewe: relationship of frequency of $\mathrm{LH}$ pulses to day length and the response to oestradiol negative feedback. Biol. Reprod. 33, 324-334.

Steel, R.G.D. \& Torrie, J. (1980) Principles and Procedures of Statistics. McGraw-Hill, NY.

Thomas, G.B., Pearse, D.T., Oldham, C.M., Martin, G.B. \& Lindsay, D.R. (1988) Effects of breed, ovarian steroids and season on the pulsatile secretion of LH in ovariectomized ewes. J. Reprod. Fert. 84, 313-324.

Webb, R., Baxter, G., Preece, R.D., Land, R.B. \& Springbett, A.J. (1985) Control of gonadotrophin release in Scottish Blackface and Finnish Landrace ewes during seasonal anoestrus. J. Reprod. Fert. 73, 369-378.

Received 26 June 1991 